ISSN 1678-3921

Journal homepage: www.embrapa.br/pab

For manuscript submission and journal contents, access: www.scielo.br/pab

\section{Spatial variability of soil physical attributes in integrated production systems in the Amazon region}

\begin{abstract}
The objective of this work was to analyze the spatial variability of soil physical attributes in integrated production systems and its relationship with the growth and yield of a corn (Zea mays) crop intercropped with palisade grass (Urochloa brizantha). The experiment was carried out in an integrated crop-livestock (ICL) system and in an integrated crop-livestock-forestry (ICLF) system, in a Plinthic Hapludox. The ICLF system was managed in alleys between eucalyptus (Eucalyptus spp.) rows, spaced at 18, 30, and 42 $\mathrm{m}$. Corn grain and forage yields were positively correlated with soil clay and moisture contents, whereas grain yield was negatively correlated with soil penetration resistance. The lowest corn plant heights and grain yields were observed near eucalyptus rows. The average values for soil penetration resistance were below 2.0 $\mathrm{MPa}$. Spatial variability was verified for: corn plant height, grain yield, and agronomic efficiency; forage intercropping; and soil moisture and silt contents, as well as penetration resistance. Greater grain and biomass yields were obtained at a 42-m distance between tree rows. The obtained results are indicative that corn traits and soil physical attributes were only slightly associated. The spatial distribution of the eucalyptus rows influences the agronomic efficiency of the intercrop and soil moisture contents.
\end{abstract}

Index terms: Eucalyptus, Urochloa brizantha, agronomic efficiency, precision agriculture, soil compaction, soil variability.

\section{Variabilidade espacial de atributos físicos do solo em sistemas integrados de produção na região amazônica}

Resumo - O objetivo deste trabalho foi analisar a variabilidade espacial de atributos físicos do solo em sistemas de produção integrada e a sua relação com o crescimento e a produtividade da cultura de milho (Zea mays) consorciada com braquiária (Urochloa brizantha). O experimento foi conduzido em sistema de integração lavoura-pecuária (ILP) e em sistema de integração lavoura-pecuária-floresta (ILPF), em Latossolo VermelhoAmarelo distrófico plintossólico. O sistema de ILPF foi manejado em aleias, com renques de eucaliptos (Eucalyptus spp.) espaçados a 18, 30 e 42 $\mathrm{m}$. As produtividades de grãos de milho e de forragem se correlacionaram positivamente com os conteúdos de argila e de água no solo, enquanto a produtividade de grãos se correlacionou negativamente com a resistência do solo à penetração. As menores alturas de plantas e produtividade de grãos de milho foram observadas próximo aos renques de eucalipto. Os valores médios de resistência à penetração estiveram abaixo de 2,0 MPa. Verificou-se 
variabilidade espacial para: altura de plantas, produtividade de grãos e eficiência relativa do milho; consórcio com foragem; e conteúdo de água e silte no solo, bem como resistência do solo à penetração. As maiores produtividades de grãos e de biomassa foram obtidas à distância de $42 \mathrm{~m}$ entre os renques. Os resultados obtidos são indicativos de que os caracteres do milho estiveram apenas levemente associados aos atributos físicos do solo. A distribuição espacial dos renques de eucalipto influencia a eficiência relativa do consócio e a umidade do solo.

Termos para indexação: Eucalyptus, Urochloa brizantha, eficiência agronômica, agricultura de precisão, compactação do solo, variabilidade do solo.

\section{Introduction}

Pastures in Northern Brazil represent $30 \%$ of the area with forages in the country (Almeida et al., 2016). In the state of Rondônia, livestock plays a crucial role in economy, with more than 9.8 million heads of cattle distributed over approximately 6.0 million hectares of pastures (IBGE, 2018). In 2015, most of these areas already showed some degree of soil degradation (Almeida et al., 2016).

The sustainable land use by integrated crop-livestockforestry (ICLF) systems can promote environmental, social, and economic benefits by intensifying agricultural productivity in a same area (Balbinot Junior et al., 2009). This technology can also improve soil fertility and increase productivity due to the diversification of agricultural activities, aggregating value to them via sustainability and, consequently, improving the quality of life of farmers (Balbino et al., 2011). Moreover, because of all these characteristics, integrated systems can enhance the "land-saving effect" of those activities, reducing the deforestation of tropical forest areas in the Amazon, for example (Vilela et al., 2012).

As a management strategy, precision agriculture can improve soil management by determining spatial and temporal variations in soil attributes and their effects on plant yield (Inamasu \& Bernardi, 2014). The application of geostatistical methods is an important tool to characterize and evaluate the spatial distribution of the attributes of both soil and plants (Yamamoto \& Landim, 2013). In this context, integrated farming systems are more complex to handle than nonintegrated ones, since they commonly show greater heterogeneity regarding soil attributes.
The spatial variability of soil attributes, therefore, can significantly affect crop productivity in different cropping systems (Vian et al., 2016). However, few studies on the subject are available for the Amazon region, despite their possible contribution in defining crop arrangements for sustainable practices.

The objective of this work was to analyze the spatial variability of soil physical attributes in integrated production systems and its relationship with the growth and yield of a corn crop intercropped with palisade grass.

\section{Materials and Methods}

The study was carried out in the experimental field of Embrapa Rondônia (between coordinates 406272S, 9027783W and 406897S, 9027312W), in the state of Porto Velho, Brazil. The soil type is a Latossolo Vermelho-Amarelo distrófico plintossólico (Passos et al., 2017), i.e., a Plinthic Hapludox, with a clayey-silt texture.

The experimental site was divided into two main areas with different integrated cropping systems. The first area, with an integrated crop-livestock (ICL) system, was managed since 2012 under no-tillage, with soybean [Glycine $\max$ (L.) Merr.] in summer and corn (Zea mays L.) intercropped with palisade grass [Urochloa brizantha (A.Rich.) R.D.Webster], cultivar Xaraés, in winter (Townsend et al., 2013). The other area, consisting of an ICLF system, was managed in alleys between four rows of eucalyptus (Eucalyptus spp.), planted in March 2013, spaced at 18, 30, and $42 \mathrm{~m}$ (Figure 1).

The following soil attributes were evaluated at three depths $(0.00-0.10,0.10-0.20$, and $0.20-0.40 \mathrm{~m})$ : penetration resistance; coarse sand, fine sand, silt, and clay contents; and moisture content. The SoloTrack automatic penetrometer (Falker, Porto Alegre, RS, Brazil) was used to measure penetration resistance between the corn sowing lines. Soil sampling was done with a rectangular mesh $(240 \times 480 \mathrm{~m})$, with a $30 \times 30-\mathrm{m}$ resolution, totaling 128 plots. Soil texture and moisture contents were analyzed in 32 points systematically selected throughout the areas. Data were collected one week before the LG 6038 PRO corn hybrid seeds previously treated with $4 \mathrm{~mL} \mathrm{~kg}^{-1}$ Imidacloprid - were sown in January 2016, simultaneously to U. brizantha 'Xaraés'. The spacing between rows was $0.90 \mathrm{~m}$, and 
the initial population was 65 thousand plants per hectare.

The number of corn plants and ears was determined in $7.2-\mathrm{m}^{2}$ plots $\left(8.0 \times 0.9 \mathrm{~m}^{2}\right)$, randomly placed within each $900-\mathrm{m}^{2}$ mesh plot (Cargnelutti Filho et al., 2011). The plant height of five plants per sampling point was measured. After threshing, grain yield, ear index (number of ears per plant), and plant population were assessed.

Forage samples were taken from $1.0-\mathrm{m}^{2}$ plots, randomly distributed within the $900-\mathrm{m}^{2}$ mesh plots, and then weighed and dried in an oven at $60^{\circ} \mathrm{C}$, for 72 hours, in order to determine dry matter yield $\left(\mathrm{Mg} \mathrm{ha} \mathrm{a}^{-1}\right)$. The general production (GProd) at each sampling point was obtained by summing forage dry matter yield and corn grain yield. The relative agronomic efficiency index was calculated by dividing the GProd, in each sampling point, by the average GProd measured in the ICL system.

The descriptive statistics were calculated to verify central tendency measures (mean and median), data dispersion (standard deviation and coefficient of variation), asymmetry, and kurtosis. The geoR package of the $\mathrm{R}$ software ( $\mathrm{R}$ Core Team, 2015) was used to analyze the spatial structure of the data after the adjustment of semivariograms. Trends were considered in second degree models (Ribeiro Jr \& Diggle, 2001). The Cressie \& Hawkins (1980) estimator was adopted because of its robustness, even with the presence of outliers:

$$
2 \gamma_{\mathrm{CH}}(\mathrm{h})=\left[\frac{1}{\mathrm{~N}(\mathrm{~h})} \sum_{\mathrm{i}=1}^{\mathrm{N}(\mathrm{h})}\left|\left(\mathrm{Z}\left(\mathrm{x}_{\mathrm{i}}+\mathrm{h}\right)-\mathrm{Z}\left(\mathrm{x}_{\mathrm{i}}\right)\right)\right|^{\frac{1}{2}}\right]^{4} /\left(0.457+\frac{0.494}{\mathrm{~N}(\mathrm{~h})}\right),
$$

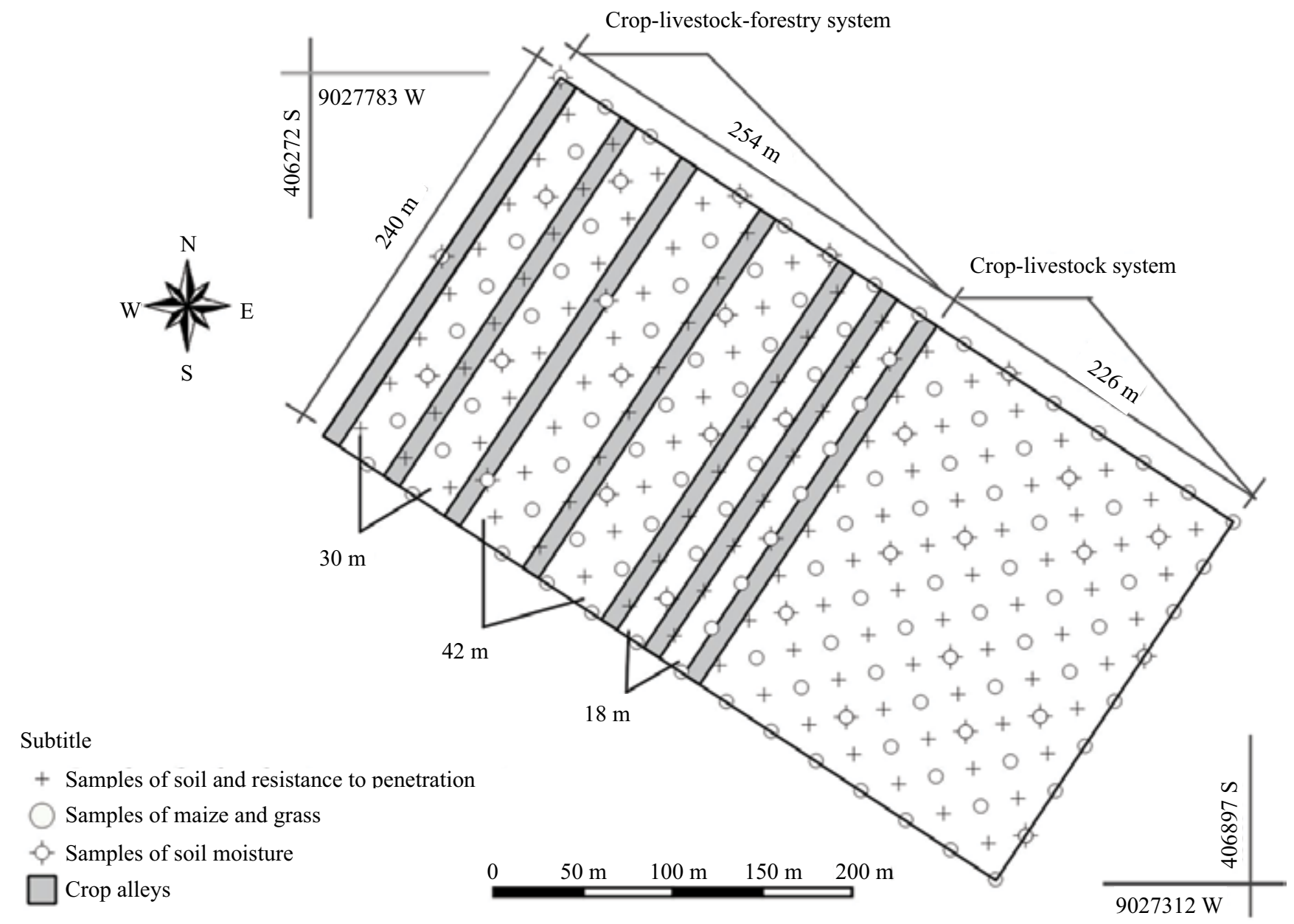

Figure 1. Spatial arrangement of the evaluated integrated production systems, with the collection sites of soil, corn (Zea mays) plant, and forage grass (Urochloa brizantha) samples. 
where $\gamma(\mathrm{h})$ is the value of the semivariance estimate at distance $h ; N(h)$ is the number of sample pairs separated by a distance $\mathrm{h}$; and pairs $\mathrm{Z}\left(\mathrm{x}_{\mathrm{i}}+\mathrm{h}\right)$ and $\mathrm{Z}\left(\mathrm{x}_{\mathrm{i}}\right)$ are the observed numerical values of an attribute $Z$ sampled at point $x_{i}+h$ and at point $x_{i}$, respectively.

Semivariogram parameters were adjusted for four theoretical models: exponential, Gaussian, spherical, and wave, using the nonlinear least square estimation procedure. The best theoretical model was chosen through a validation method, consisting of the four following steps: autovalidation; estimation of the mean error of the validation results; estimation of the standard error of the mean; and estimation of the root mean square error.

The degree of spatial dependence (SD) was obtained by dividing the nugget effect $\left(\mathrm{C}_{0}\right)$ by the sill (sum of $\mathrm{C}_{0}$ and contribution), then multiplying the result by 100 (Cambardella et al., 1994).

The maps were made with the universal kriging interpolator, which allows performing this task without a trend bias and with a minimum variance of the prediction error, spatially correlating the neighboring samples for the later construction of the isoline maps (Grego et al., 2014). The classical Pearson correlation was tested in the IswR package (Dalgaard, 2008).

\section{Results and Discussion}

Data on corn plant population, plant height, and ear index, as well as on soil moisture, and silt and clay contents (Table 1), all showed classical homogeneity $-\mathrm{CV}<12 \%$ (Warrick \& Nielsen, 1980) for the three evaluated depths. A moderate variation $(12 \%<\mathrm{CV}<60 \%)$ was found for corn grain yield, forage dry matter yield, relative agronomic efficiency index, and also for soil penetration resistance, coarse sand content in the $0.00-0.10-\mathrm{m}$ layer, and fine sand content at all depths.

The mean grain yield was $3.53 \mathrm{Mg} \mathrm{ha}^{-1}$ in the 2015/2016 crop season, and the highest values were observed in the

Table 1. Descriptive statistics for corn (Zea mays) plant population (1,000 plants per hectare), plant height, ear index, and grain yield, as well as for forage dry matter yield, agronomic efficiency index, and soil penetration resistance (MPa) and contents of coarse sand, fine sand, silt, clay, and moisture at three depths, in the integrated crop-livestock-forestry system.

\begin{tabular}{|c|c|c|c|c|c|c|c|c|}
\hline Variable & Soil depth (m) & $\mathrm{N}$ & Average & Median & $\mathrm{SD}^{(1)}$ & $\mathrm{CV}(\%)$ & Assymetry & Kurtosis \\
\hline Plant population & - & 104 & 39.77 & 40.28 & 4.41 & 11.10 & -0.09 & -0.37 \\
\hline Plant height (m) & - & 104 & 2.62 & 2.67 & 0.18 & 7.06 & -2.69 & 10.73 \\
\hline Ear index (ears per plant) & - & 104 & 0.99 & 1.00 & 0.04 & 3.87 & -2.93 & 13.11 \\
\hline Grain yield $\left(\mathrm{Mg} \mathrm{ha}^{-1}\right)$ & - & 104 & 3.53 & 3.59 & 0.97 & 27.46 & -0.34 & -0.29 \\
\hline Forage yield $\left(\mathrm{Mg} \mathrm{ha}^{-1}\right)$ & - & 103 & 0.93 & 0.87 & 0.48 & 51.44 & 0.90 & 0.85 \\
\hline Agronomic efficiency index & - & 103 & 0.82 & 0.83 & 0.22 & 26.76 & -0.19 & -0.58 \\
\hline \multirow{3}{*}{$\begin{array}{l}\text { Penetration resistance } \\
(\mathrm{MPa})\end{array}$} & $0.00-0.10$ & 120 & 1.40 & 1.30 & 0.38 & 26.98 & 0.63 & 3.00 \\
\hline & $0.10-0.20$ & 120 & 1.99 & 1.93 & 0.31 & 15.85 & 1.12 & 2.75 \\
\hline & $0.20-0.40$ & 120 & 1.36 & 1.34 & 0.21 & 15.45 & 0.95 & 2.06 \\
\hline \multirow{3}{*}{ Coarse sand (dag kg $\left.{ }^{-1}\right)$} & $0.00-0.10$ & 32 & 1.63 & 1.00 & 0.93 & 56.81 & 1.25 & 0.43 \\
\hline & $0.10-0.20$ & 32 & 1.50 & 1.00 & 0.90 & 60.01 & 1.64 & 1.56 \\
\hline & $0.20-0.40$ & 32 & 1.37 & 1.00 & 0.96 & 70.56 & 1.48 & 1.56 \\
\hline \multirow{3}{*}{ Fine sand (dag $\mathrm{kg}^{-1}$ ) } & $0.00-0.10$ & 32 & 16.30 & 15.50 & 3.31 & 20.32 & 0.47 & -1.10 \\
\hline & $0.10-0.20$ & 32 & 16.40 & 17.00 & 3.05 & 18.58 & 0.30 & -0.90 \\
\hline & $0.20-0.40$ & 32 & 16.53 & 16.00 & 3.42 & 20.69 & 0.25 & -1.29 \\
\hline \multirow{3}{*}{ Silt (dag kg $\left.{ }^{-1}\right)$} & $0.00-0.10$ & 32 & 42.63 & 43.00 & 2.97 & 6.95 & 0.24 & -0.36 \\
\hline & $0.10-0.20$ & 32 & 41.83 & 41.50 & 2.85 & 6.82 & 0.52 & -0.46 \\
\hline & $0.20-0.40$ & 32 & 40.37 & 40.00 & 3.24 & 8.03 & 0.29 & -0.47 \\
\hline \multirow{2}{*}{ Clay (dag kg-1) } & $0.00-0.10$ & 30 & 39.43 & 40.00 & 3.64 & 9.22 & -0.38 & -0.85 \\
\hline & $0.10-0.20$ & 30 & 40.27 & 41.00 & 3.82 & 9.49 & -0.39 & -0.81 \\
\hline \multirow{3}{*}{ Moisture $\left(\mathrm{kg} \mathrm{kg}^{-1}\right)$} & $0.00-0.10$ & 32 & 0.26 & 0.26 & 0.02 & 7.42 & -0.58 & 0.29 \\
\hline & $0.10-0.20$ & 32 & 0.27 & 0.27 & 0.02 & 7.05 & -0.30 & -0.73 \\
\hline & $0.20-0.40$ & 32 & 0.27 & 0.27 & 0.02 & 7.42 & -0.24 & -1.12 \\
\hline
\end{tabular}

${ }^{(1)} \mathrm{SD}$, spatial dependence. 
ICL system, with an average of $4.27 \mathrm{Mg} \mathrm{ha}^{-1}$, and the lowest, in the ICLF system, with an average of 2.93 $\mathrm{Mg} \mathrm{ha}^{-1}$. In the ICLF system, the highest grain and dry biomass yields ( $4.51 \mathrm{Mg} \mathrm{ha}^{-1}$ ) were found in the alleys spaced at $42 \mathrm{~m}$, and the lowest ones $\left(1.51 \mathrm{Mg} \mathrm{ha}^{-1}\right)$, obtained by interpolation, at $18-\mathrm{m}$ spacing. Townsend et al. (2013) reported a similar average grain yield in the same area, while evaluating the ICLF system + ICL system, in the 2009/2010 crop season.

In both systems, the mean population of 65,000 corn plants per hectare was lower than expected, which may be related to sowing procedures. The average ear index was 0.99 ear per plant, and $17.3 \%$ of the plots had plants without ears, while $7.7 \%$ had plants with more than one ear.

The average dry matter yield of grass forage was $0.93 \mathrm{Mg} \mathrm{ha}^{-1}$, and the highest value of $1.15 \mathrm{Mg} \mathrm{ha}^{-1}$ was obtained in the ICL system; however, even this yield can be considered unsatisfactory (Cunha et al., 2012). The highest agronomic efficiency was verified in plots in the ICL system, since $60.42 \%$ of them showed an index equal to or higher than 1 , which was not observed for any of the ICLF plots.

The highest values of soil penetration resistance occurred at the $0.10-0.20-\mathrm{m}$ depth. When evaluating an Oxisol under an ICL system, Conte et al. (2011) reported the presence of soil compaction $(>2.0 \mathrm{MPa})$ on the surface layer $(0.00-0.10 \mathrm{~m})$, after cattle treading, and in the subsurface $(0.10-0.20 \mathrm{~m})$, after soybean harvest in a no-tillage system. Since, in the present study, penetration resistance was measured after soybean harvest, the greater compaction caused by the harvest operation in the $0.10-0.20$-m layer is in alignment with those results.

As to soil moisture, homogeneity was observed at all analyzed depths. This is an important variable in soil compaction studies because it shows a spatial relationship inversely proportional to penetration resistance (Campos et al., 2013).

The soil texture analyses indicated the predominance of clay and silt in the $0.20-0.40-\mathrm{m}$ layer, with increased contents of clay (39.4 to $41.7 \mathrm{dag} \mathrm{kg}^{-1}$ ) and fine sand (16.30 to $16.53 \mathrm{dag}^{-1}$ ) at greater depths.

Corn and grass growth and yield were positive and linearly correlated with soil clay and moisture contents in the $0.00-0.20$ and $0.20-0.40-\mathrm{m}$ layers. However, except for the ear index, these variables were negatively correlated with fine sand contents. Corn grain yield also showed a positive correlation with corn plant population, plant height, and ear index, besides a negative correlation with soil penetration resistance in the $0.00-0.10$ and $0.20-0.40-\mathrm{m}$ layers; however, the latter was a weak association.

Soil penetration resistance had a weak negative correlation with soil moisture on the most superficial layer of $0.00-0.10 \mathrm{~m}$, as well as a weak correlation with corn grain yield. Therefore, penetration resistance values in soils with a high variability in moisture content underestimate soil compaction values (Bergamin et al., 2010), making it difficult to determine the critical limit for a proper crop development.

The following variables showed spatial autocorrelation: corn plant height, grain yield, and agronomic efficiency index; and soil moisture content in the $0.00-0.10-\mathrm{m}$ layer, silt content in the $0.10-0.20-\mathrm{m}$ layer, and penetration resistance in all three layers (Table 2). Plant height was adjusted to the exponential model, whereas corn grain yield and soil penetration resistance were better adjusted to the spherical model. For the other variables, a wave behavior was observed, indicating the sensitivity of the variables to the presence of eucalyptus rows in the area, making the spatial structure cyclical or periodic due to the regular geometry (line spacing) of these rows. It should be noted that the cited theoretical models are often used in soil variability studies (Cavalcante et al., 2011; Marasca et al., 2011).

A pure nugget effect was modeled to soil moisture, which may be related to the sample spacing used to detect spatial variability (Vieira et al., 2011) or to the random data distribution resulting from homogenization due to successive soil cultivation (Bottega et al., 2013). The absence of detectable SD on soil moisture, in deeper layers, may be associated with the percolation of water in depth, which homogenizes its distribution along the soil profile, with a greater variability on superficial layers. In this case, the conservationist management may have promoted, over time, the stabilization of soil physical attributes, which resulted in the homogenization and randomness of the variable. Studies have identified spatial variability for texture, over a wide range of spacing, from $2 \times 2 \mathrm{~m}$ (Cavalcante et al., 2011) to 100x100 m (Vieira et al., 2011), for example.

Soil penetration resistance in the $0.10-0.40-\mathrm{m}$ layer, moisture content in the $0.00-0.10-\mathrm{m}$ layer, and 
silt content in the $0.10-0.20$-m layer showed strong SD $(\leq 25 \%)$. Moderate SD $(25<\mathrm{SD}<75 \%)$ was verified for corn plant height and grain yield, as well as for the agronomic efficiency index and soil penetration resistance on the most superficial layer. This result is an indicative of a nonrandom behavior and shows the amount of the spatial variation that explains data variability.

The range of SD changed from $20.12 \mathrm{~m}$ for soil moisture in the $0.00-0.10-\mathrm{m}$ layer to $107 \mathrm{~m}$ for corn grain yield. These results allow planning the sampling of these variables, assuming the same conditions, which cannot be done when no SD is detected between samples (Figure 2).

Despite the occurrence of isolated values of penetration resistance above $2.0 \mathrm{MPa}$, considered impeditive for the development of plant roots
(Tormena, 2009), the mean value for this variable was below the established limit. Marasca et al. (2011), however, reported values from 2.9 to $4.2 \mathrm{MPa}$ that did not compromise soybean yield in a clayey Oxisol under no-tillage for 13 years. This might be due to the minimum soil revolving practices involved in the notillage system, which allows the development of a kind of porosity that extends the critical limits commonly adopted (Tormena et al., 2007).

The lowest plant heights were obtained at the sampling points located at the center of the experimental area, in the first corn rows in relation to the eucalyptus trees. This indicates the negative influence of eucalyptus on crop growth (Figure 3); in the ICLF system, the presence of eucalyptus reduced plant height in $4.10 \%$.

Table 2. Parameters of semivariograms adjusted for corn (Zea mays) plant population, height, ear index, and grain yield, as well as for forage dry matter yield, agronomic efficiency index, and soil penetration resistance and contents of coarse sand, fine sand, silt, clay, and moisture at three depths, in the integrated crop-livestock-forestry system.

\begin{tabular}{|c|c|c|c|c|c|c|c|c|}
\hline \multirow[t]{2}{*}{ Variable } & \multirow[t]{2}{*}{ Model } & \multicolumn{7}{|c|}{ Semivariogram parameters $^{(1)}$} \\
\hline & & $\mathrm{C}_{0}$ & $\mathrm{C}_{1}$ & $\mathrm{r}$ & ME & MSE & RMSE & $\mathrm{SD}$ \\
\hline Plant population & $\mathrm{Pne}^{(2)}$ & 311.30 & - & - & - & - & - & - \\
\hline Plant height & Exponential & 0.01 & 0.01 & 73.77 & $2 \times 10^{-4}$ & $1 \times 10^{-3}$ & 0.17 & 39.28 \\
\hline Ear index & Pne & $2.19 \times 10^{-5}$ & - & - & - & - & - & - \\
\hline Grain yield & Spherical & 0.29 & 0.38 & 107.40 & $-1 \times 10^{-3}$ & $-1 \times 10^{-3}$ & 0.73 & 43.06 \\
\hline Forage yield & Pne & 0.14 & - & - & - & - & - & - \\
\hline \multirow[t]{2}{*}{ Agronomic efficiency index } & Wave & 0.02 & 0.01 & 26.79 & $-7 \times 10^{-4}$ & $-2 \times 10^{-3}$ & 0.15 & 56.96 \\
\hline & \multicolumn{8}{|c|}{$0.00-0.10-\mathrm{m}$ soil depth } \\
\hline Penetration resistance & Spherical & 0.06 & 0.06 & 50.03 & $2 \times 10^{-4}$ & $3 \times 10^{-4}$ & 0.34 & 51.98 \\
\hline Coarse sand & Pne & 0.03 & - & - & - & - & - & - \\
\hline Fine sand & Pne & 3.72 & - & - & - & - & - & - \\
\hline Silt & Pne & 3.72 & - & - & - & - & - & - \\
\hline \multirow[t]{2}{*}{ Moisture } & Wave & $2.96 \times 10^{-5}$ & $210^{-4}$ & 20.12 & $-2 \times 10^{-4}$ & -0.01 & 0.02 & 20.12 \\
\hline & \multicolumn{8}{|c|}{$0.10-0.20-\mathrm{m}$ soil depth } \\
\hline Penetration resistance & Spherical & 0.01 & 0.05 & 50.31 & $-3 \times 10^{-4}$ & $-1 \times 10^{-3}$ & 0.28 & 23.32 \\
\hline Coarse sand & Pne & 0.04 & - & - & - & - & - & - \\
\hline Fine sand & Pne & 2.21 & - & - & - & - & - & - \\
\hline Silt & Wave & 0 & 5.55 & 21.77 & 0.05 & 0.02 & 1.63 & 0 \\
\hline \multirow[t]{2}{*}{ Moisture } & Pne & $3.38 \times 10^{-5}$ & - & - & - & - & - & - \\
\hline & \multicolumn{8}{|c|}{$0.20-0.40-\mathrm{m}$ soil depth } \\
\hline Penetration resistance & Spherical & 0.01 & 0.03 & 69.00 & $1 \times 10^{-3}$ & $2 \times 10^{-3}$ & 0.20 & 23.71 \\
\hline Coarse sand & Pne & 0.05 & - & - & - & - & - & - \\
\hline Fine sand & Pne & 0.97 & - & - & - & - & - & - \\
\hline Silt & Pne & 4.98 & - & - & - & - & - & - \\
\hline Moisture & Pne & $2.81 \times 10^{-5}$ & - & - & - & - & - & - \\
\hline
\end{tabular}

${ }^{(1)} \mathrm{C}_{0}$, nugget effect; $\mathrm{C}_{1}$, contribution; r, range; ME, mean error; MSE, mean standard error; RMSE, root mean square error; and $\mathrm{SD}$, spatial dependence. (2) Pne, pure nugget effect. 
PH (Exp; 0.009; 0.014; 73.77)

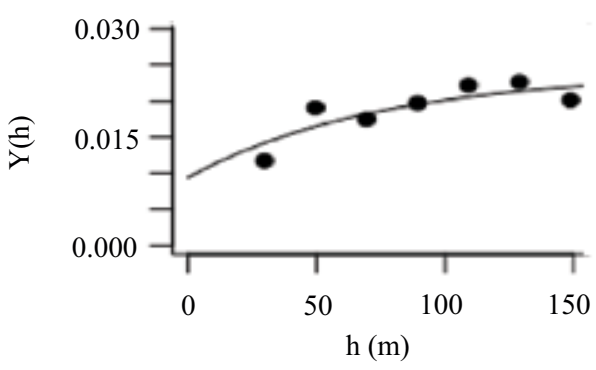

AEI (Wave; 0.016; 0.011; 26.79)

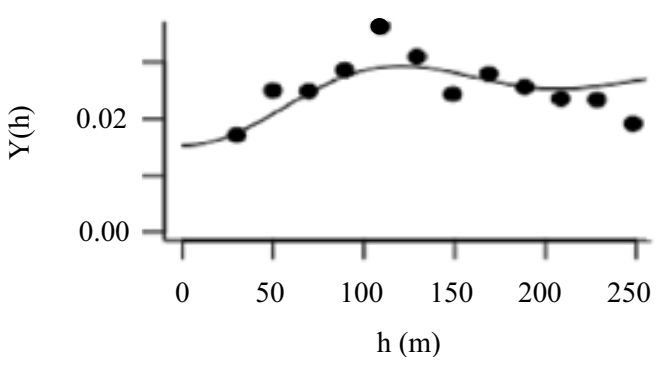

$\mathrm{RP}(0.10$ to $0.20 \mathrm{~m})$

(Esf; $0.015 ; 0.05 ; 50.31)$

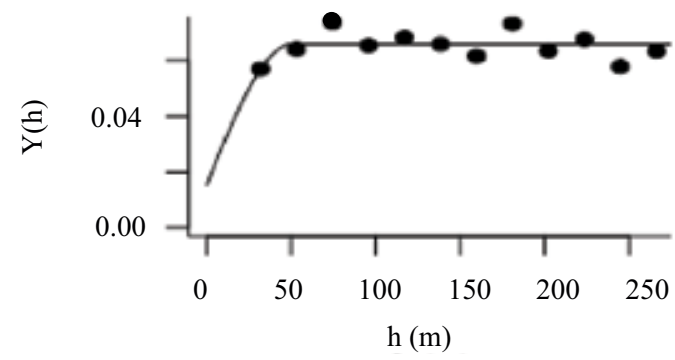

$\mathrm{SM}(0$ to $0.10 \mathrm{~m})$

(Wave; $2.96 \times 10^{-5} ; 2 \times 10^{-4} ; 20.12$ )

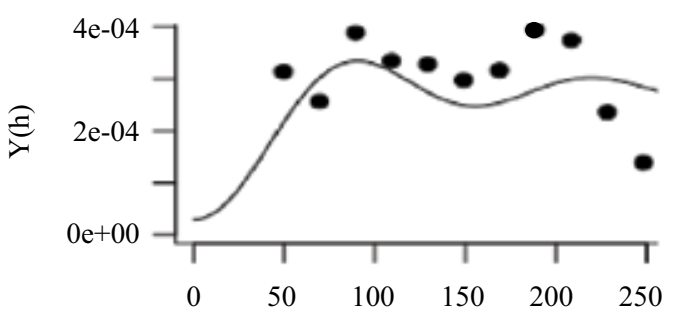

GY (Esf; 0.292; 0.385; 107.4)

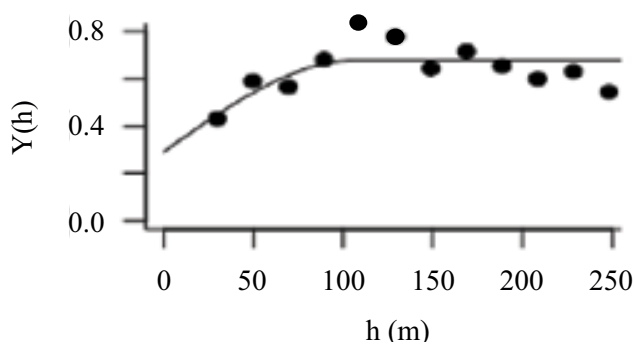

$\mathrm{RP}(0$ to $0.10 \mathrm{~m})$

(Esf; $0.061 ; 0.057 ; 50.03)$

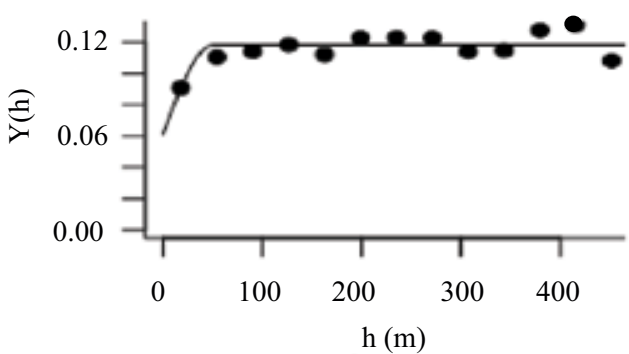

$\mathrm{RP}(0.20$ to $0.40 \mathrm{~m})$

(Esf; 0.009; 0.028; 69.0)

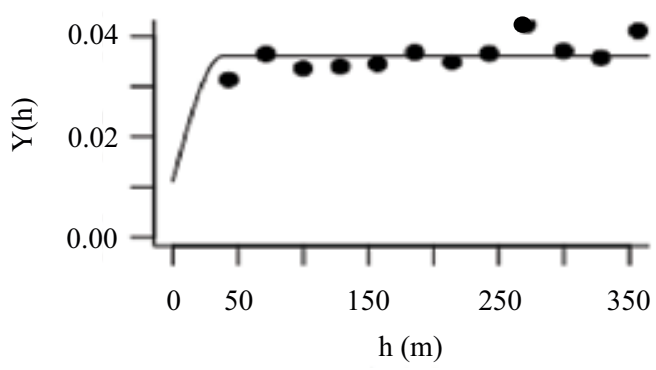

$\mathrm{S}(0.10$ to $0.20 \mathrm{~m})$

(Wave; $0 ; 5.55 ; 21.77$ )

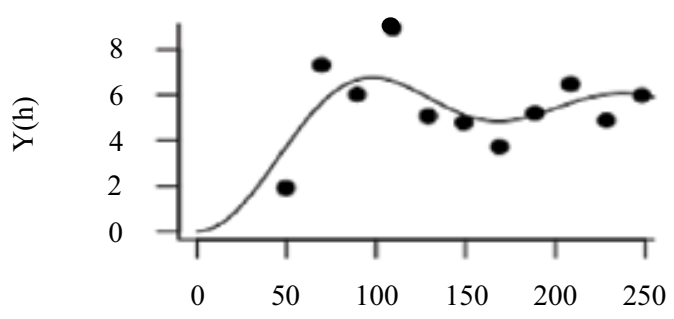

Figure 2. Semivariograms adjusted for corn (Zea mays) plant height (PH) and grain yield (GY), agronomic efficiency index (AEI), and soil penetration resistance (PR) and moisture (SM) and silt (S) contents, in the integrated crop-livestock-forestry system. Information between parenthesis denotes the adjusted models (exponential, spherical, or wave) and their parameters nugget effect, contribution, and range, respectively. 

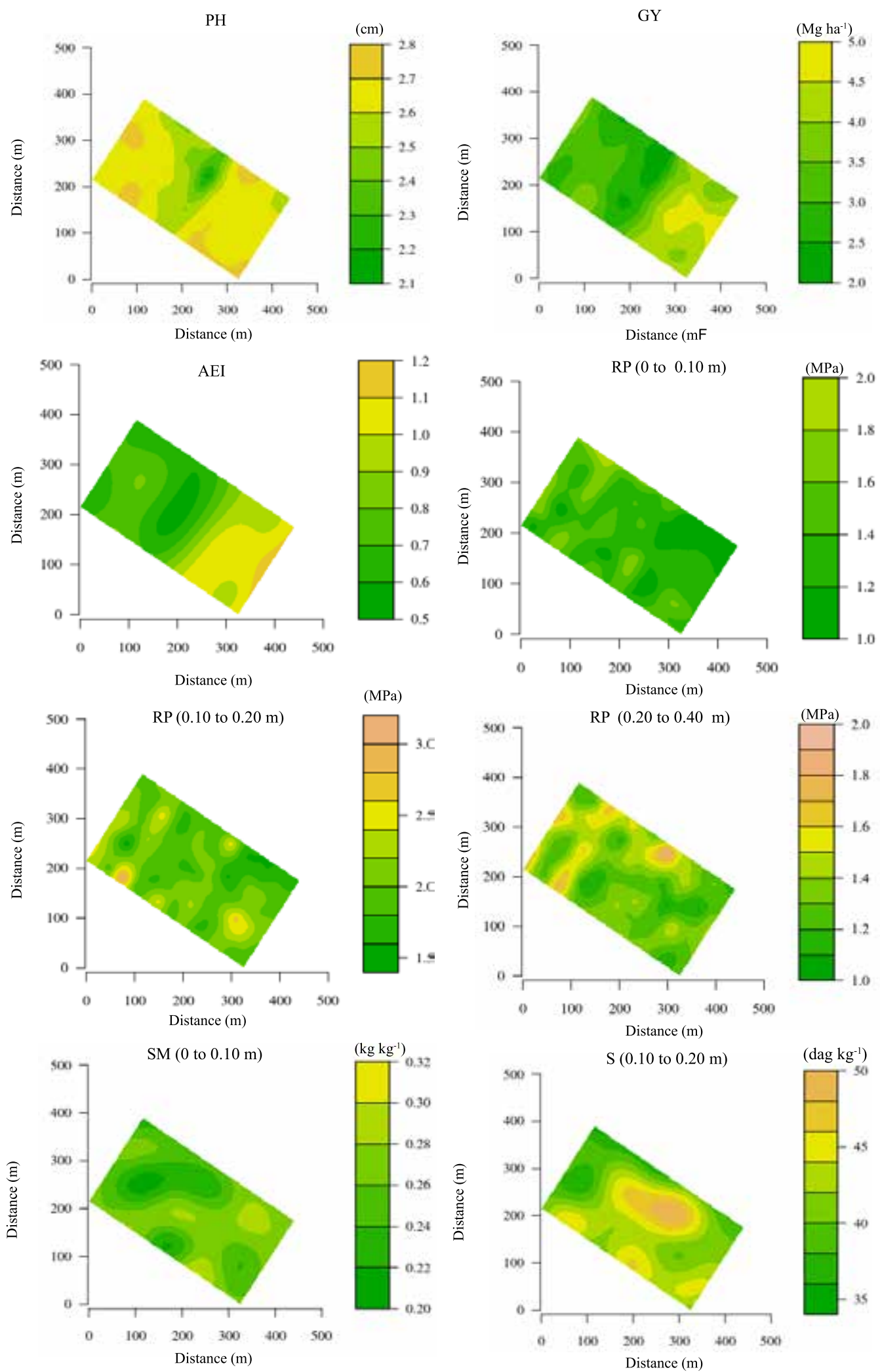

Figure 3. Kriging maps for corn (Zea mays) plant height (PH) and grain yield (GY), relative agronomic efficiency index (AEI), and soil penetration resistance (PR) and moisture (SM) and silt (S) contents. 
The spatial variability of soil moisture in the superficial layer occurred in spots, but with a low horizontal variation, showing a similar behavior to penetration resistance. For silt, the highest contents were observed in large spots, in the $0.10-0.20$-m layer, regardless of the integrated system.

The highest corn grain yields were obtained in the ICL area, and the lowest yields and plant height, in the ICLF area. Soil maps showed that grain yield was little related to spatial variation in soil compaction, at the three depths, despite the correlation found between these variables. As to the distribution of the agronomic efficiency of forage and corn grains in the area, there was a gradient effect from the ICLF system to the ICL system, so that the highest yields occurred in the latter.

For soil penetration resistance, the highest compaction levels were obtained in the subsurface layer of $0.10-0.20 \mathrm{~m}$. At the evaluated depths, there was a more localized or punctual distribution at the corridor edges between the eucalyptus rows, both for the corn rows closer to the trees and within the eucalyptus rows. The levels of penetration resistance indicate that the ICLF management reduced soil compaction when compared with the original pasture (Silva Filho et al., 2010), which showed compaction degrees reaching 7.2 $\mathrm{MPa}$, for a yellow Oxisol, and 5.4 MPa, for a red Ultisol. Therefore, crop rotation under no-tillage is an alternative to control soil compaction, since the use of species with a more aggressive root system allows the creation of biological pores (decompressing) and the input of organic matter improves soil structure (Tormena, 2009). This results in an increased soil moisture content, which reduces penetration resistance levels (Conte et al., 2011).

From the obtained results, it may be inferred that other factors related to soil fertility, such as shading (Paciullo et al., 2011) or possible allelopathic effects of eucalyptus (El-Khawas \& Shehata, 2005), may also be limiting corn grain yield in the ICLF system.

\section{Conclusions}

1. The eucalyptus (Eucalyptus spp.) rows spatially influence soil moisture contents and the agronomic efficiency index of the integrated production system, with a negative impact on corn (Zea mays) grain yield, conferring a periodic behavior to the spatial correlation structure.
2. Considering the detrimental effects of the presence of eucalyptus trees on corn and grass forage (Urochloa brizantha) growth, the crop-livestock system is preferred for higher grain and forage yields.

3. In the southwestern Amazon region, integrated crop-livestock-forestry systems should have at least $42 \mathrm{~m}$ between eucalyptus rows, allowing greater corn grain and forage dry matter yields.

\section{Acknowledgments}

To Conselho Nacional de Desenvolvimento Cientifico e Tecnológico (CNPq), for financial support (Grant No. 459130/2014-5).

\section{References}

ALMEIDA, C.A. de; COUTINHO, A.C.; ESQUERDO, J.C.D.M.; ADAMI, M.; VENTURIERI, A.; DINIZ, C.G.; DESSAY, N.; DURIEUX, L.; GOMES, A.R. High spatial resolution land use and land cover mapping of the Brazilian Legal Amazon in 2008 using Landsat-5/TM and MODIS data. Acta Amazônica, v.46, p.291302, 2016. DOI: https://doi.org/10.1590/1809-4392201505504.

BALBINO, L.C.; BARCELLOS, A. de O.; STONE, L.F. (Ed.). Marco referencial: integração lavoura-pecuária-floresta. Brasília: Embrapa Informação Tecnológica, 2011. 130p.

BALBINOT JUNIOR, A.A.; MORAES, A. de; VEIGA, M. da; PELISSARI, A.; DIECKOW, J. Integração lavoura-pecuária: intensificação de uso de áreas agrícolas. Ciência Rural, v.39, p.1925-1933, 2009. DOI: https://doi.org/10.1590/S010384782009005000107.

BERGAMIN, A.C.; VITORINO, A.C.T.; LEMPP, B.; SOUZA, C.M.A. de; SOUZA, F.R. de. Anatomia radicular de milho em solo compactado. Pesquisa Agropecuária Brasileira, v.45, p.299-305, 2010. DOI: https://doi.org/10.1590/S0100-204X2010000300010.

BOTTEGA, E.L.; QUEIROZ, D.M. de; PINTO, F. de A. de C.; SOUZA, C.M.A. de. Variabilidade espacial de atributos do solo em sistema de semeadura direta com rotação de culturas no cerrado brasileiro. Revista Ciência Agronômica, v.44, p.1-9, 2013.

CAMBARDELLA, C.A.; MOORMAN, T.B.; NOVAK, J.M.; PARKIN, T.B.; KARLEN, D.L.; TURCO, R.F.; KONOPKA, A.E. Field-scale variability of soil properties in central Iowa soils. Soil Science Society of America Journal, v.58, p.1501-1511, 1994. DOI: https://doi.org/10.2136/sssaj1994.03615995005800050033x.

CAMPOS, M.C.C.; AQUINO, R.E. de; OLIVEIRA, I.A. de; BERGAMIM, A.C. Variabilidade espacial da resistência mecânica do solo à penetração e umidade do solo em área cultivada com cana-de-açúcar na região de Humaitá, Amazonas, Brasil. Revista Brasileira de Ciências Agrárias, v.8, p.305-310, 2013. DOI: https://doi.org/10.5039/agraria.v8i2a2091.

CARGNELUTTI FILHO, A.; TOEBE, M.; BURIN, C.; CASAROTTO, G.; LÚCIO, A.D. Métodos de estimativa do tamanho ótimo de parcelas experimentais de híbridos de milho 
simples, triplo e duplo. Ciência Rural, v.41, p.1509-1516, 2011. DOI: https://doi.org/10.1590/S0103-84782011000900004.

CAVAlCANTE, E.G.S.; ALVES, M.C.; SOUZA, Z.M. de; PEREIRA, G.T. Variabilidade espacial de atributos físicos do solo sob diferentes usos e manejos. Revista Brasileira de Engenharia Agrícola e Ambiental, v.15, p.237-243, 2011. DOI: https://doi.org/10.1590/S1415-43662011000300003.

CONTE, O.; FLORES, J.P.C.; CASSOL, L.C.; ANGHINONI, I.; CARVALHO, P.C. de F.; LEVIEN, R.; WESP, C. de L. Evolução de atributos físicos de solo em sistema de integração lavoura-pecuária. Pesquisa Agropecuária Brasileira, v.46, p.1301-1309, 2011.

CRESSIE, N.; HAWKINS, D.M. Robust estimation of the variogram: I. Mathematical Geology, v.12, p.115-125, 1980.

CUNHA, F.F. da; RAMOS, M.M.; ALENCAR, C.A.B. de; OLIVEIRA, R.A. de; CÓSER, A.C.; MARTINS, C.E.; CECON, P.R.; ARAUUJO, R.A.S. Produtividade da Brachiaria brizantha cv. Xaraés em diferentes manejos e doses de adubação, períodos de descanso e épocas do ano. Idesia, v.30, p.75-82, 2012. DOI: https://doi.org/10.4067/S0718-34292012000100009.

DALGAARD, P. Introductory statistics with R. 2.ed. New York: Springer, 2008. DOI: https://doi.org/10.1007/978-0-387-79054-1

EL-KHAWAS, S.A.; SHEHATA, M.M. The allelopathic potentialities of Acacia nilotica and Eucalyptus rostrata on monocot (Zea mays L.) and dicot (Phaseolus vulgaris L.) plants. Biotechnology, v.4, p.23-34, 2005. DOI: https://doi.org/10.3923/ biotech.2005.23.34.

GREGO, C.R.; OLIVEIRA, R.P. de; VIEIRA, S.R. Geoestatística aplicada a agricultura de precisão. In: BERNARDI, A.C. de C.; NAIME, J. de M.; RESENDE, A.V. de; BASSOI, L.H.; INAMASU, R.Y. (Ed.). Agricultura de precisão: resultados de um novo olhar. Brasília: Embrapa, 2014. p.74-83.

IBGE. Instituto Brasileiro de Geografia e Estatística. Censo agropecuário 2017: resultados preliminares. Available at: $<$ https://sidra.ibge.gov.br/pesquisa/censo-agropecuario/censoagropecuario-2017\#pecuaria>. Accessed on: Oct. 102018.

INAMASU, R.Y.; BERNARDI, A.C. de C. Agricultura de precisão. In: BERNARDI, A.C.de C.; NAIME, J. de M.; RESENDE, A.V. de; BASSOI, L.H.; INAMASU, R.Y. (Ed.). Agricultura de precisão: resultados de um novo olhar. Brasília: Embrapa, 2014. p.21-33.

MARASCA, I.; OLIVEIRA, C.A.A. de; GUIMARÃES, E.C.; CUNHA, J.P.A.R. da; ASSIS, R.L. de; PERIN, A.; MENEZES, L.A.S. Variabilidade espacial da resistência do solo à penetração e teor de água em sistema de plantio direto, na cultura da soja. Bioscience Journal, v.27, p.239-246, 2011.

PACIULLO, D.S.C.; GOMIDE, C.A.M.; CASTRO, C.R.T. de; FERNANDES, P.B.; MÜLLER, M.D.; PIRES, M. de F.Á.; FERNANDES, E.N.; XAVIER, D.F. Características produtivas e nutricionais do pasto em sistema agrossilvipastoril, conforme a distância das árvores. Pesquisa Agropecuária Brasileira, v.46, p.1176-1183, 2011. DOI: http://doi.org/10.1590/S0100204X2011001000009.
PASSOS, A.M.A. dos; AKER, A.M.; COSTA, R.S.C. da; SANTOS, F.C. dos; LEITE, V.P.D.; MARCOLAN, A.L. Effect of cover crops on physico-chemical attributes of soil in a shortterm experiment in the southwestern Amazon region. African Journal of Agricultural Research, v.12, p.3339-3347, 2017. DOI: https://doi.org/10.5897/AJAR2017.12800.

R CORE TEAM. R: a language and environment for statistical computing. Vienna: R Foundation for Statistical Computing, 2015.

RIBEIRO JR, P.J.; DIGGLE, P.J. geoR: a package for geostatistical analysis. R-News, v.1/2, p.15-18, 2001.

SILVA FILHO, E.P. da; COTTAS, L.R.; MARINI, G.B.S. Avaliação da compactação dos solos em áreas de pastagens e florestas em Porto Velho-Rondônia. Boletim de Geografia, v.28, p.145-155, 2010. DOI: https://doi.org/10.4025/bolgeogr.v28i1.8441.

TORMENA, C.A. Compactação dos solos em SPD precisa ser atenuada. Revista Visão Agrícola, n.9, p.194-197, 2009. TORMENA, C.A.; ARAÚJO, M.A.; FIDALSKI, J.; COSTA, J.M. da. Variação temporal do intervalo hídrico ótimo de um Latossolo Vermelho distroférrico sob sistemas de plantio direto. Revista Brasileira de Ciência do Solo, v.31, p.211-219, 2007. DOI: https://doi.org/10.1590/S0100-06832007000200003.

TOWNSEND, C.R.; PASSOS, A.M.A. dos; GODINHO, V. de P.C.; MARCOLAN, A.L.; UTUMI, M.M.; BOTELHO, F.J.E.; TEIXEIRA, J.F.; OLIVEIRA, S.J. de M.; ARAÚJO, L.V. de; TEIXEIRA, C.A.D.; COSTA, J.N.M. iLPF como alternativa sustentável de recuperação de pastagem degradada em Porto Velho, Rondônia. Porto Velho: Embrapa Rondônia, 2013. (Embrapa Rondônia. Documentos 154).

VIAN, A.L.; SANTI, A.L.; AMADO, T.J.C.; CHERUBIN, M.R.; SIMON, D.H.; DAMIAN, J.M.; BREDEMEIER, C. Variabilidade espacial da produtividade de milho irrigado e sua correlação com variáveis explicativas de planta. Ciência Rural, v.46, p.464-471, 2016. DOI: https://doi.org/10.1590/0103-8478cr20150539.

VIEIRA, S.R.; DECHEN, S.C.F.; SIQUEIRA, G.M.; DUFRANC, G. Variabilidade espacial de atributos físicos e químicos relacionados com o estado de agregação de dois Latossolos cultivados no sistema de semeadura direta. Bragantia, v.70, p.185-195, 2011.

VILELA, L.; MARTHA JR, G.B.; MARCHÃO, R.L. Integração lavoura-pecuária-floresta: alternativa para intensificação do uso da terra. Revista UFG, ano13, p.92-99, 2012.

WARRICK, A.W.; NIELSEN, D.R. Spatial variability of soil physical properties in the field. In: HILLEL, D. (Ed.). Applications of soil physics. New York: Academic Press, 1980. p.319-344. DOI: https://doi.org/10.1016/B978-0-12-348580-9.50018-3.

YAMAMOTO, J.K.; LANDIM, P.M.B. Geoestatística: conceitos e aplicações. São Paulo: Oficina de Textos, 2013. 